\title{
PENGARUH PARTISIPASI PENYUSUNAN ANGGARAN, BUDAYA ORGANISASI DAN GAYA KEPEMIMPINAN TERHADAP KINERJA APARAT PEMERINTAH DAERAH DENGAN KOMITMEN ORGANISASI SEBAGAI VARIABEL PEMODERASI Studi pada Pemerintah Daerah Kabupaten Temanggung
}

\author{
Arin Sulistyaningsih \\ Rohmad Yuliantoro
}

\begin{abstract}
This research is aimed to examine the effect of budget arragement participation, organization culture and leadership style toward local goverment officials performance, with organization commitment as moderating variable on local government of Temanggung. Budget is an effective short tem arrangement, high scale of budget arragement participation,organization culture and leadership style toward local goverment officials performance, and organization commitmen can support budget run well. Populations in this research are local government officials in SKPD Temanggung. Object in this research are head of division, division head, sub-division head and section head, data collection methode in this research with survei and questionaire. Data analysis technique used in this research are double linier regression and moderated regression analysis. The results of this research show that budget arrangement participation and leadership style influence the local government performance, organization commitment can moderate organization culture effect and leadership style toward local government performance, but it can not moderate budget arrangement participation effect toward local government officials performance.
\end{abstract}

Keywords: budget arragement participation, organization culture, leadership style, local goverment officials performance, organization commitment.

\section{PENDAHULUAN}

Anggaran dalam sektor publik merupakan instrumen akuntabilitas atas pengelolaan dana publik dan pelaksanaan program-program yang dibiayai dengan uang publik. Proses penganggaran organisasi sektor publik dimulai ketika perumusan strategi dan perencanaan strategik telah selesai dilakukan sehingga tahap penganggaran menjadi sangat penting karena anggaran yang tidak efektif dan tidak beroreientasi pada kinerja akan dapat menggagalkan perencanaan yang sudah disusun (Mardiasmo, 2005: 61). Partisipasi anggaran adalah salah satu cara menciptakan sistem pengendalian manajemen yang baik sehingga diharapkan dapat tercapai tujuan institusi yang terkait. 
Penelitian yang membahas hubungan antara partisipasi dalam proses penyusunan anggaran terhadap kinerja aparat pemerintah masih sering diperdebatkan. Menurut (Brownell dan Mc. Innes 1986); (Indriantoro, 1993); (Trisnawati, 2000); (Falikhatun, 2005); (Nor, 2007) dalam Arifin (2012: 3) menemukan bahwa partisipasi penyusunan anggaran dan kinerja memiliki hubungan yang positif. Berbeda dengan penelitian yang dilakukan oleh Milani (1975); Brownell dan Hirst (1986) dalam Wulandari (2011), yang menemukan hasil yang tidak signifikan antara partisipasi penyusunan anggaran dengan kinerja aparat pemerintah daerah.

Menurut Holmes dan Marsden (1996) dalam Ayuningtiyas (2013), budaya organisasi menjadi dasar untuk memahami perasaan saling memahami bagi karyawan mengenai instansi mereka, bagaimana segala sesuatu dikerjakan berdasarkan pengertian bersama tersebut dan bagaimana caranya karyawan bersikap. Gaya kepemimpinan menurut David dan Keith dalam Baihaqi (2010) adalah kemampuan untuk mempengaruhi orang lain untuk mencapai tujuan dengan antusias. Menurut Glynn (1993) dalam Wulandari (2011) kinerja aparat pemerintah daerah merupakan salah satu faktor yang dapat digunakan untuk meningkatkan efektivitas organisasi.

Desentralisasi di sektor pemerintahan terjadi dari kepala daerah satuan kerja perangkat daerah (SKPD), satuan kerja pengelola keuangan daerah (SKPKD) dan sekertaris daerah. Desentralisasi dalam hal ini adalah penyerahan wewenang dari pemerintah pusat kepada pemerintah daerah untuk mengurus urusan yang ada di daerah tersebut. Masing-masing satuan kerja perangkat daerah (SKPD) menyusun format rencana kerja dan anggaran (RKA) SKPD. Komitmen organisasi sebagai tolok ukur bagi aparat pemerintah daerah memihak pada suatu organisasi serta untuk mempertahankan keanggotannya dalam suatu organisasi (Sumarno, 2005 dalam Wulandari, 2011).

Penelitian ini mengambil objek riset pada Pemerintah Daerah Kabupaten Temanggung, hal ini didasarkan pada Target dan Realisasi APBD Kabupaten Temanggung Tahun Anggaran 2010-2012. Secara umum pelaksanaan APBD Kabupaten Temanggung Tahun Anggaran 2008-2013 sudah relatif baik namun 
masih ada kekurangan yang dilakukan oleh Pemerintah Kabupaten Temanggung yaitu masih kurang baiknya perencanaan kegiatan terutama perencanaan anggaran sehingga masih dijumpai adanya SiLPA yang cukup tinggi tiap tahunnya. Oleh karena itu, penelitian yang akan dilakukan ini bermaksud untuk mengetahui pengaruh partisipasi penyusunan anggaran, budaya organisasi, dan gaya kepemimpinan terhadap kinerja aparat pemerintah daerah dengan komitmen organisasi sebagai variabel pemoderasi, studi pada pemerintah daerah Kabupaten Temanggung.

\section{TINJAUAN PUSTAKA PERUMUSAN MASALAH}

\section{Teori Kontijensi}

Fisher (1998) dalam Noviyanti (2014) berpendapat bahwa teori kontijensi dalam pengendalian manajemen muncul dari adanya sebuah asumsi dasar pendekatan pandangan umum, pendekatan pengendalian pandangan umum merupakan kenyataan dari manajemen ilmiah. Pendekatan dalam rangka kontijensi memungkinkan adanya variabel-variabel lain dapat bertindak sebagai faktor pemoderasi yang mempengaruhi hubungan antara partisipasi penyusunan anggaran dengan kinerja aparat pemerintah daerah (Wahyudin, 2007 dalam Susilowati, 2014).

\section{Partispasi Penyusunan Anggaran}

Partisipasi merupakan suatu proses individu-individu yang terlibat langsung didalamnya dan mempunyai pengaruh pada penyusunan target anggaran yang kinerjanya akan dievaluasi dan kemungkinan akan dihargai atas dasar pencapaian target (Anthony dan Govindarajan, 2009). Anggaran merupakan alat penting untuk perencanaan dan pengendalian jangka pendek yang efektif dalam organisasi, yang biasanya meliputi waktu satu tahun dan menyatakan pendapat dan beban yang direncanakan untuk tahun itu.

Menurut Mardiasmo (2002: 63) anggaran sektor publik mempunyai beberapa fungsi utama, yaitu anggaran sebagai alat perencanaan (planning tool), anggaran sebagai alat pengendalian (control tool), anggaran sebagai alat kebijakan fiskal (fiscal tool), anggaran sebagai alat politik (political tool), anggaran sebagai alat koordinasi dan komunikasi (coordination and communication tool), anggaran 
sebagai alat penilaian kinerja (performance measurement tool), anggaran sebagai alat motivasi (motivation tool), dan anggaran sebagai alat untuk menciptakan ruang publik (public sphree).

\section{Budaya Organisasi}

Budaya organisasi merupakan nilai-nilai atau norma-norma yang mengarahkan perilaku anggota organisasi sangat penting, yaitu sebagai penentu arah yang boleh dilakukan dan arah yang tidak boleh dilakukan, mengelola dan mengalokasikan sumber daya organisasi serta sebagai alat untuk menghadapi masalah dan peluang dari lingkungan internal dan eksternal. Robbin (2006: 41) menyatakan bahwa budaya organisasi mengacu ke sistem bersama yang dianut oleh anggota-anggota yang membedakan organisasi ini dari organisasi lain.

\section{Gaya Kepemimpinan}

Gaya kepemimpinan merupakan perilaku atau cara yang dipilih dan digunakanpemimpin dalam mempengaruhi pikiran, perasaan, sikap dan perilaku para anggota organisasi bawahannya (Nawawi, 2003 dalam Ayuningtias 2013). Menurut Rivai dalam Mariam (2009), kepemimpinan juga dikatakan sebagai proses mengarahkan dan mempengaruhi aktivitas-aktivitas yang ada hubungannya dengan pekerjaan para anggota kelompok. Adapun gaya kepemimpinan yaitu, kepemimpinan otoriter, kepemimpinan demokratis, dan kepemimpinan bebas.

\section{Kinerja Aparat Pemerintah Daerah}

Menurut Pabundu (2006) dalam Noviyanti (2014) mendefinisikan kinerja sebagai hasil-hasil fungsi pekerjaan/kegiatan seseorang atau kelompok dalam suatu organisasi yang dipengaruhi oleh beberapa faktor untuk mencapai tujuan organisasi dalam perioda waktu tertentu. Faktor-faktor yang mempengaruhi kinerja menurut Sutermeister (1999) dalam Wulandari (2011) terdiri dari motivasi, kemampuan, pengetahuan, keahlian, pendidikan, pengalaman, pelatihan, minat, sikap kepribadian, kondisi-kondisi fisik dan kebutuhan fisiologis, kebutuhan sosial dan kebutuhan egoistik.

Menurut Mardiasmo (2002: 74) Satuan Kerja Perangkat Daerah (SKPD 
merupakan pusat pertanggungjawaban yang dipimpin oleh seorang kepala satuan kerja dan bertanggungjawab atas entitasnya, misalnya: dinas kesehatan, dinas kependudukan dan catatan sipil, dinas pendidikan, dinas pemuda dan olah raga, dan lainnya. Kinerja suatu unit kerja pemerintah daerah dapat diukur melalui pencapaian aktivitas-aktivitas yang dibiayai oleh APBD.

\section{Komitmen Organisasi}

Robbin (1998) dalam Larasati (2009) menyatakan komitmen merupakan suatu orientasi sikap individu terhadap nilai-nilai dan organisasi kerja, sedangkan menurut Usmara (2004) dalam Susilowati (2013) komitmen organisasi merupakan hasil interaksi dari setiap elemen-elemen perilaku organisasi. Wujud orientasi sikap berupa kemampuan identifikasi kondisi organisasi, kemampuan terlibat aktif, dimilikinya rasa setia dan kepemilikan terhadap organisasi.

\section{Pengaruh Partisipasi Penyusunan Anggaran terhadap Kinerja Aparat Pemerintah Daerah Kabupaten Temanggung}

Partisipasi anggaran dan pengukuran kinerja dalam organisasi sektor publik tidak sebatas pada masalah pemakaian anggaran, namun pengukuran kinerja mencakup aspek yang dapat memberikan informasi yang efisien dan efektif dalam mencapai hasil yang diinginkan kinerja. Sikap dan perilaku anggota organisasi dalam penyusunan anggaran perlu melibatkan manajemen pada level yang lebih rendah sehingga anggaran partisipatif dapat dinilai sebagai pendekatan manajerial yang dapat meningkatkan kinerja setiap anggota organisasi sebagai individu karena dengan adanya partispasi dalam penyusunan anggaran diharapkan setiap individu mampu meningkatkan kinerjanya sesuai dengan target yang telah ditentukan (Bambang Sardjito dan Osmad Muthaher, 2007 dalam Arifin 2012).

Meidaty (2013), Ayuningtias (2013), dan Noviyanti (2014) dalam penelitiannya menunjukkan hasil yang sama bahwa partisipasi penyusunan anggaran berpengaruh terhadap kinerja aparat pemerintah daerah. Berdasarkan penjelasan tersebut, dapat disusun hipotesis sebagai berikut:

$\mathrm{H}_{1}$ : Partisipasi penyusunan anggaran berpengaruh terhadap kinerja aparat daerah Temanggung. 


\section{Pengaruh Budaya Organisasi terhadap Kinerja Aparat Pemerintah Daerah Kabupaten Temanggung.}

Budaya organisasi merupakan nilai-nilai dari keyakinan yang dimiliki para anggota organisasi yang dituangkan dalam bentuk norma-norma perilaku para individu atau kelompok organisasi ditempat individu tersebut bekerja (Hofdtede at.al 1990) dalam Arifin (2012).

Penelitian Purwandani (2012) dan Ayuningtias (2013) menunjukkan bahwa partisipasi penyusunan anggaran dan budaya organisasi berpengaruh terhadap kinerja aparat aparat pemerintah daerah. Berdasarkan penjelasan tersebut, dapat disusun hipotesis sebagai berikut:

$\mathrm{H}_{2}$ : Budaya organisasi berpengaruh terhadap kinerja aparat pemerintah daerah Kabupaten Temanggung.

\section{Pengaruh Gaya Kepemimpinan Terhadap Kinerja Aparat Pemerintah Daerah Kabupaten Temanggung.}

Menurut posolong (2008) dalam Noviyanti (2014) hubungan antara gaya kepemimpinan dengan kinerja sangat erat kaitannya, bahwa pilihan gaya kepemimpinan yang tidak tepat, maka kinerja birokrasi akan menurun, serta bawahan dapat merasakan frustasi, kebencian, kegelisahan, dan ketidakpuasan. Peranan pimpinan sangat penting dalam usaha mencapai tujuan suatu tujuan organisasi, sehingga dapat diketahui keberhasilan atau kegagalan yang dialami, sebagian besar ditentukan oleh kualitas pimpinan. Pilihan gaya kepemimpinan yang menghubungkan secara tepat dengan kinerja individu maupun organisasi merupakan suatu mitivasi eksternal yang dapat menjadi acuan dalam pencapaian tujuan yang ditentukan untuk itu seorang pemimpin juga harus dapat mengembangkan gaya kepemimpinan yang mampu meningkatkan kinerja aparat pemerintah daerah.

Penelitian yang menunjukkan adanya pengaruh yang antara gaya kepemimpinan dengan kinerja aparat pemerintah daerah yaitu penelitian yang dilakukan oleh Fertalis (1986) dan Sumarno (2005). Berdasarkan penjelasan tersebut, dapat disusun hipotesis sebagai berikut:

$\mathrm{H}_{3}$ : Pengaruh gaya kepemimpinan terhadap kinerja aparat pemerintah daerah 
Kabupaten Temanggung.

\section{Komitmen Organisasi Mampu Memoderasi Partisipasi Penyusunan Anggaran terhadap Kinerja Aparat Pemerintah Daerah Kabupaten Temanggung.}

Menurut sumarno (2005) dalam Wulandari (2011) komitmen organisasi adalah dorongan dari dalam individu untuk berbuat sesuatu agar dapat menunjang keberhasilan organisasi sesuai dengan tujuan dan lebih mengutamakan kepentingan organisasi dari kepentingan sendiri. Komitmen organisasi sebagai tolok ukur sejauh mana aparat pemerintah daerah memihak pada suatu organisasi serta untuk mempertahankan keanggotannya sebagai suatu organisasi. Komitmen yang tinggi menjadikan individu lebih mementingkan organanisasi dari kepentingan pribadi dan menjadikan organisasi yang menjadi lebih baik.

Penelitian Wulandari (2011) menunjukkan bahwa partisipasi penyusunan anggaran berpengaruh terhadap kinerja aparat daerah dan komitmen organisasi sebagai variabel pemoderasi. Berdasarkan penjelasan tersebut, dapat disusun hipotesis sebagai berikut:

$\mathrm{H}_{4}$ : Komitmen organisasi mampu memoderasi partisipasi penyusunan anggaran terhadap kinerja aparat pemerintah daerah Kabupaten Temanggung

\section{Komitmen organisasi mampu memoderasi budaya organisasi terhadap kinerja aparat pemerintah daerah Kabupaten Temanggung.}

Komitmen organisasi juga merupakan faktor yang perlu diperhatikan dalam peningkatan kinerja. Berkaitan dengan rangka manajemen berbasis kinerja setiap individu bertanggung jawab atas kinerja. Individu yang memiliki komitmen organisasi akan menghasilkan kinerja demi tercapainya tujuan organisasi. Apabila setiap pegawai memiliki komitmen yang kuat untuk memberikan prestasi terbaiknya bagi negara dan pelayanan terbaik bagi masyarakat, maka tentunya kinerja sektor publik akan meningkat (Rafika, 2009 dalam Noviyanti, 2014).

Menurut Holmes dan Marsden (1996) dalam Ayuningtias (2013) budaya organisasi menjadi dasar untuk memahami perasaan saling memahami bagi karyawan mengenai instansi mereka, bagaimana segala sesuatu dikerjakan berdasarkan pengertian bersama tersebut dan bagaimana cara instansi bersikap. 
Instansi pun harus dapat memadukan karakter-karakter budaya organisasi yang ada untuk menciptakan suatu instansi. Budaya organisasi mempunyai pengaruh terhadap perilaku, cara kerja serta motivasi para manajer dan bawahannya untuk mencapai kinerja organisasi. Berdasarkan penjelasan tersebut, dapat disusun hipotesis sebagai berikut:

$\mathrm{H}_{5}$ : Komitmen organisasi mampu memoderasi budaya organisasi terhadap kinerja aparat pemerintah daerah Kabupaten Temanggung.

\section{Komitmen organisasi mampu memoderasi gaya kepemimpinan terhadap kinerja aparat pemerintah daerah Kabupaten Temanggung.}

Komitmen organisasi menurut Maier \& Brunstei (2001) dalam Baihaqi (2010) merupakan kondisi saat karyawan sangat tertarik terhadap tujuan, nilai-nilai dan sasaran organisasinya, sedangkan gaya kepemimpinan adalah pola tingkah laku yang dirancang untuk mengintegrasikan tujuan organisasi dengan tujuan individu untuk mencapai tujuan tertentu. Bagi seorang pemimpin dalam menghadapi situasi yang menuntut aplikasi gaya kepemimpinannya dapat melalui beberapa proses seperti: memahami gaya kepemimpinannya, mendiagnosa suatu situasi, menerapkan gaya kepemimpinan yang relevan dengan tuntutan situasi atau dengan mengubah situasi agar sesuai dengan gaya kepemimpinannya. Hal ini akan mendorong timbulnya itikad baik atau komitmen anggota terhadap organisasinya, sehingga seseorang akan lebih bekerja keras dalam mencapai tujuan organisasi.

Penelitian Desianty (2005) dalam Baihaqi (2010) menunjukkan ada hubungan yang signifikan antara gaya kepemimpinan dan komitmen organisasi. Berdasarkan penjelasan tersebut, dapat disusun hipotesis sebagai berikut:

H6: Komitmen organisasi mampu memoderasi gaya kepemimpinan terhadap kinerja aparat pemerintah daerah Kabupaten Temanggung.

\section{METODA PENELITIAN}

\section{Populasi dan sampel}

Populasi dalam penelitian ini adalah karyawan Satuan Kerja Perangkat Daerah (SKPD). Alasan dipilihnya populasi dan lokasi penelitian tersebut adalah ingin 
mengetahui tingkat partisipasi di SKPD Kabupaten Temanggung. Teknik pengambilan sampel dalam penelitian ini menggunakan metoda purposive sampling. Kriteria sampel dalam penelitian ini yaitu kepala bagian, kepala bidang, kepala subbagian, kepala subbidang dan kepala seksi di SKPD di Kabupaten Temanggung. Teknik pengumpulan data dalam penelitian ini dilakukan dengan cara survei.

\section{Definisi Operasional Variabel}

\section{Partisipasi Penyusunan Anggaran}

Brownell (1986) mendefinisikan partisipasi anggaran sebagai suatu proses partisipasi individu akan dievaluasi dan mungkin diberi penghargaan berdasarkan prestasi mereka pada sasaran. Penelitian ini menggunakan instrumen yang telah digunakan oleh Noviyanti (2014) untuk mengukur variabel partisipasi penyusunan anggaran.Variabel partisipasi penyusunan anggaran menggunakan 5 skala Likert. Skor terendah (1) dari jawaban responden menunjukkan rendahnya partisipasi penyusunan anggaran, sebaliknya skor tinggi (5) menunjukkan tingginya partisipasi penyusunan yang ada.

\section{Budaya Organisasi}

Budaya organisasi dapat diartikan sebagai totalitas dan pola perilaku keyakinan, kelembagaan, seni, dan produk pikiran manusia yang menjadi karakteristik dari suatu lingkungan sosial. Variabel budaya organisasi menggunakan 5 skala Likert.. Skor terendah (1) dari jawaban responden menunjukkan rendahnya budaya organisasi, sebaliknya skor tinggi (5) menunjukkan tingginya budaya organisasi yang ada.

\section{Gaya Kepemimpinan.}

Gaya kepemimpinan merupakan cara/teknik yang dituang dalam sikap dan perilaku seseorang pemimpin dalam mengarahkan dan memperngaruhi kelompok/bawahan agar dapat dan mau berusaha untuk mencapai tujuan yang ditetapkan. Variabel gaya kepemimpinan menggunakan 5 skala Likert.. Skor terendah (1) dari jawaban responden menunjukkan rendahnya gaya kepemimpinan, sebaliknya skor tinggi (5) menunjukkan tingginya gaya kepemimpinan yang ada. 


\section{Kinerja Aparat Pemerintah Daerah}

Kinerja aparat dilihat berdasarkan kemampuan aparat dalam melaksanakan tugas-tugas menejerial yang meliputi perencanaan, investigasi, koordinasi, supervise, pengaturan staf, negosiasi dan representasi (Mahonay dalam Ayuningtias 2013). Variabel kinerja aparat pemerintah daerah menggunakan 5 skala Likert.. Skor terendah (1) dari jawaban responden menunjukkan rendahnya kinerja aparat pemerintah daerah, sebaliknya skor tinggi (5) menunjukkan tingginya kinerja aparat pemerintah daerah yang ada.

\section{Komitmen Organisasi}

Komitmen organisasi diartikan sebagai suatu keinginan yang kuat untuk menjadi anggota dari suatu organisasi. Keinginan ini ditujukan dengan mengerahkan segala upaya atas nama organisasi dengan suatu keyakinan, penerimaan nilai dan tujuan organisasi tertentu (Mowday, 1982 dalam Ayuningtias 2013. Variabel komitmen organisasi menggunakan 5 skala Likert.. Skor terendah (1) dari jawaban responden menunjukkan rendahnya komitmen organisasi, sebaliknya skor tinggi (5) menunjukkan komitmen organisasi daerah yang ada.

\section{Teknis Analisis Data}

\section{Uji Kualitas Data}

Penelitian ini menggunakan data primer berupa kuesioner, sehingga diperlukan uji kualitas data yang terdiri atas uji validitas dan reliabilitas data.

\section{Analisis Regresi Berganda}

Model hubungan variabel-variabel tersebut disusun dalam persamaan sebagai berikut:

$$
\mathbf{Y}=\mathbf{a}+\boldsymbol{\beta}_{1} \mathbf{X}_{1}+\boldsymbol{\beta}_{2} \mathbf{X}_{2}+\mathbf{B}_{3} \mathbf{X}_{3}+\mathbf{e}
$$

Keterangan:

Y : Kinerja aparat pemerintah daerah

a : Konstanta

$\beta 1-\beta 3 \quad$ : Koefisien regresi

$\mathrm{X} 1 \quad$ : Partisipasi penyusunan anggaran

X2 : Budaya Organisasi 
X3 : Gaya Kepemimpinan

E : Error

\section{Uji Asumsi Klasik}

\section{Uji Normalitas}

Uji normalitas bertujuan untuk menguji ada tidaknya variabel pengganggu atau residual yang memiliki distribusi tidak normal dalam model regresi. Uji statistik yang digunakan untuk menguji normalitas residual adalah uji statistik nonparametrik one-sample Kolmogorov-Smirnov (K-S). Dasar pengambilan keputusan dengan uji normalitas ini adalah dengan melihat nilai asymp sig : (2 tailed). Jika nilai asymp sig: 2-tailed > alpha $(\alpha)$, maka residual berdistribusi normal, dan sebaliknya (Ghozali, 2006: 147-151).

\section{Uji Heteroskedastisitas}

Uji heteroskedastisitas bertujuan untuk menguji ada atau tidaknya ketidaksamaan variance dari residual satu pengamatan ke pengamatan yang lain dalam model regresi. Uji statistik yang digunakan dalam penelitian untuk mengetahui ada tidaknya heteroskedastisitas yaitu uji Glejser. Jika nilai signifikansi diatas nilai alpha $(\alpha)$, maka model regresi tidak mengandung adanya heteroskedastisitas (Ghozali, 2006: 125-129).

\section{Uji Autokorelasi}

Uji autokorelasi bertujuan untuk menunjukkan bahwa model regresi linier ada atau tidaknya hubungan antara kesalahan pengganggu pada perioda t-1 (sebelumnya). Teknik pengujian autokorelasi dapat dilakukan dengan DurbinWatson test (Ghozali, 2006: 99-100).

\section{Uji Hipotesis}

Pengujian hipotesis 1 sampai 3 dalam penelitian ini menggunakan uji regresi berganda. Dasar pengambilan keputusan pada uji $\mathrm{t}$ ini adalah dengan melihat nilai signifikansi. Jika nilai signifikansi < alpha $(\alpha)$, pengaruh partisipasi penyusunan anggaran terhadap kinerja aparat pemerintah daerah, dan sebaliknya 


\section{Moderated Regression Analysis (MRA)}

Penelitian ini menggunakan MRA untuk menguji variabel moderasi pada hipotesis $4\left(\mathrm{H}_{4}\right)$, hipotesis $5\left(\mathrm{H}_{5}\right)$, dan hipotesis $6\left(\mathrm{H}_{6}\right)$. MRA menggunakan pendekatan analitik yang mempertahankan integritas sampel dan memberikan dasar untuk mengontrol pengaruh variabel moderator (Ghozali, 2011: 225-226).

\section{Goodness of fit Model Regresi}

\section{Uji Hipotesis}

\section{Koefisien Determinasi $\left(\mathbf{R}^{2}\right)$}

Penelitian ini menggunakan nilai adjusted $R^{2}$ pada saat mengevaluasi model yang terbaik. Semakin besar nilai adjusted $R_{2}$ atau mendekati 1 , maka besar pula kemampuan model menerangkan variasi variabel independen (Ghozali, 2006: 87).

\section{Uji Signifikansi Simultan (Uji statistik F)}

Uji statistik $\mathrm{F}$ pada dasarnya menunjukkan semua variabel independen atau bebas secara bersama-sama terhadap variabel dependen terikat dalam suatu model (Ghozali, 2006: 84). Dasar pengambilan keputusan pada uji F ini adalah dengan melihat nilai probabilitas signifikansi $5 \%$ atau 0,05 . Jika nilai signifikansi, tingkat kepercayaan $(\alpha)$, maka terdapat pengaruh secara bersama-sama variabel independen terhadap variabel dependen dan sebaliknya (Ghozali, 2006: 88-91).

\section{Uji Signifikansi Parameter Individual (Uji statistik $t$ )}

Uji statistik t pada dasarnya menunjukkan pengaruh variabel independen secara individual dalam menerangkan variasi variabel dependen. Uji t digunakan untuk menguji hipotesis 1 sampai dengan 3 pada penelitian ini. Pengambilan keputusan pada uji $\mathrm{t}$ ini adalah dengan melihat nilai probabilitas signifikansi. Jika nilai probabilitas signifikansi < tingkat kepercayaan $(\alpha)$, maka variabel independen secara individu mempengaruhi variabel dependen dan sebaliknya (Ghozali, 2006: 88). 


\section{Model Penelitian}

Variabel Independen

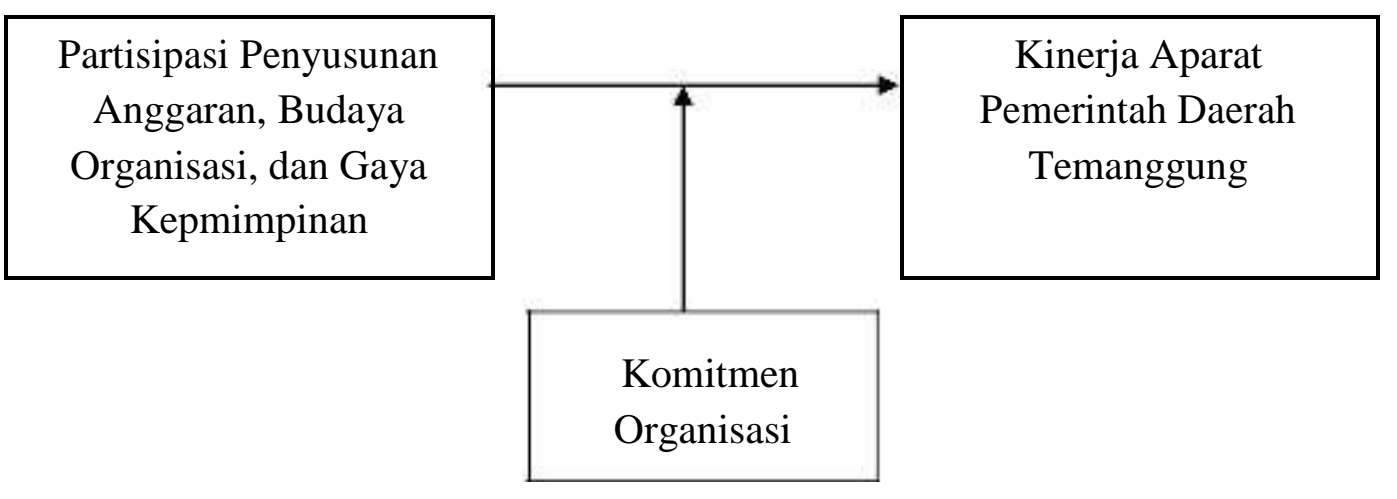

Variabel Pemoderasi

Gambar 1

Rerangka penelitian

\section{HASIL DAN PEMBAHASAN}

Penelitian ini dari 60 kuesioner yang telah memenuhi kriteria untuk diolah 27 orang di antaranya laki-laki dan 33 orang di antaranya perempuan. Rata-rata usia responden di atas 46 tahun dan sebagian besar pendidikan terakhir responden adalah tingkat $\mathrm{S} 1$.

Tabel 1

Demografi Responden

\begin{tabular}{|l|l|l|l|}
\hline \multicolumn{2}{|c|}{ Keterangan } & Frekuensi & \multicolumn{1}{c|}{ Presentase } \\
\hline Jenis Kelamin & Laki-laki & 27 & $45 \%$ \\
& Perempuan & 33 & $55 \%$ \\
\hline Usia & 21-35 Tahun & 6 & $10 \%$ \\
& 36-45 Tahun & 26 & $43 \%$ \\
& $>46$ Tahun & 28 & $47 \%$ \\
\hline Pendidikan & SLTA & 6 & $10 \%$ \\
& S1 & 34 & $57 \%$ \\
& S2 & 16 & $27 \%$ \\
& D3 & 4 & $6 \%$ \\
\hline
\end{tabular}

Sumber: Data Primer, diolah (2014)

\section{Uji Kualitas Data}

Hasil uji validitas menunjukkan bahwa semua indikator valid. Sementara itu, hasil uji reliabilitas terhadap masing-masing kuesioner pengukuran variable 
menunjukkan bahwa kuesioner yang digunakan dalam penelitian ini secara statistik layak digunakan sebagai alat pengumpul data, karena syarat valditas dana reliabilitasnya telah terpenuhi.

\section{Analisis Regresi Linier Berganda}

\section{Uji Asumsi Klasik}

\section{a. Uji Normalitas}

Hasil uji normalitas pada tabel 2 menunjukkan bahwa besarnya nilai asymp. sig. (2-tailed) adalah 0,942 lebih besar dari nilai alpha (0,05). Dengan demikian, diketahui bahwa data residual terdistribusi secara normal.

Tabel 2

Hasil Uji Normalitas

\begin{tabular}{|l|c|c|}
\hline \multicolumn{1}{|c|}{ Keterangan } & $\begin{array}{c}\text { Unstandardized } \\
\text { Residual }\end{array}$ & Alpha \\
\cline { 1 - 2 } $\mathrm{N}$ & 60 & \multirow{2}{*}{0,05} \\
\cline { 1 - 2 } asymp. sig. (2-tailed) & 0,942 & \\
\hline
\end{tabular}

Sumber: Data primer, diolah (2014).

\section{b. Uji Heteroskedastisitas}

Hasil yang ditunjukkan oleh tabel 3 menunjukkan nilai signifikansi untuk variabel independen lebih besar dari nilai alpha $(0,05)$. Berdasar hasil tersebut, diketahui bahwa model regresi tidak terdapat heteroskedastisitas.

Tabel 3

Hasil Uji Heteroskedastisitas

\begin{tabular}{|l|c|c|}
\hline \multicolumn{1}{|c|}{ Keterangan } & Signifikansi & Alpha \\
\hline $\begin{array}{l}\text { Partisipasi Penyusunan } \\
\text { Anggaran }\end{array}$ & 0,335 & 0,05 \\
\hline Budaya Organisasi & 0,467 & 0,05 \\
\hline Gaya Kepemimpinan & 0,133 & 0,05 \\
\hline
\end{tabular}

Sumber: Data primer, diolah (2014) 


\section{c. Uji Autokorelasi}

Tabel 4

Hasil Uji Autokorelasi

\begin{tabular}{|c|c|c|}
\hline Model & Durbin-Watson & dU \\
\hline 1 & 1,933 & 1,6889 \\
\hline
\end{tabular}

Sumber: Data primer, diolah (2014)

Berdasar hasil yang ditunjukkan oleh tabel 4 diperoleh nilai $\mathrm{DW}=1,933$ lebih besar dari dU $(1,6889)$ dan kurang dari $4-\mathrm{dU}(2,311)$. Berdasar hasil tersebut, diketahui bahwa tidak terdapat autokorelasi positif maupun negatif pada model regresi.

\section{Uji Hipotesis}

Tabel 5

Hasil Analisis Regresi Linier Berganda

\begin{tabular}{|c|c|c|c|c|c|c|c|c|c|}
\hline variabel & $\begin{array}{c}\text { Konst } \\
\text { anta }\end{array}$ & \begin{tabular}{|l|} 
Unstandardiz \\
ed \\
Coefficients \\
$(\beta)$
\end{tabular} & $\mathbf{F}$ & \begin{tabular}{|l} 
Adjust \\
ed $R^{2}$
\end{tabular} & Sig. & $\begin{array}{c}\text { Al } \\
\text { ph } \\
\text { a }\end{array}$ & T hitung & T tabel & Keputusan \\
\hline $\begin{array}{l}\text { Partisipasi } \\
\text { Penyusunan } \\
\text { Anggaran }\end{array}$ & \multirow{3}{*}{6,686} & 0,333 & \multirow{3}{*}{18,374} & \multirow{3}{*}{0,469} & 0,001 & \multirow{3}{*}{0,05} & 3,354 & 1,673 & $\begin{array}{c}\mathrm{H} 1 \\
\text { diterima }\end{array}$ \\
\hline $\begin{array}{l}\text { Budaya } \\
\text { Organisasi }\end{array}$ & & 0,200 & & & 0,137 & & 1,510 & & H2 ditolak \\
\hline $\begin{array}{l}\text { Gaya } \\
\text { Kepemimpinan }\end{array}$ & & 0,286 & & & 0,002 & & 3,301 & & $\begin{array}{c}\mathrm{H} 3 \\
\text { diterima }\end{array}$ \\
\hline
\end{tabular}

Sumber: Data primer, diolah (2014)

Hasil dari analisis regresi linier berganda menunjukkan bahwa:

1. Hipotesis 1 menunjukkan nilai koefisien regresi variabel partisipasi penyusunan anggaran sebesar 0,333 dan nilai signifikansi 0,001. Nilai signifikansi $(0,001)$ lebih kecil dari alpha $(0,05)$, maka hipotesis 1 dalam penelitian ini diterima. Jadi, partisipasi penyusunan anggaran berpengaruh terhadap kinerja aparat pemerintah daerah.

2. Hipotesis 2 menunjukkan nilai koefisien regresi variabel budaya organisasi anggaran sebesar 0,200 dan nilai signifikansi 0,137 . Nilai signifikansi $(0,137)$ lebih besar dari alpha $(0,05)$, maka hipotesis 2 dalam penelitian ini ditolak. Jadi, 
budaya organisasi tidak berpengaruh terhadap kinerja aparat pemerintah daerah.

3. Hipotesis 3 menunjukkan nilai koefisien regresi variabel gaya kepemimpinan sebesar 0,286 dan nilai 0,002. Nilai signifikansi $(0,002)$ lebih kecil dari alpha $(0,05)$, maka hipotesis 3 dalam penelitian ini diterima. Jadi, gaya kepemimpinan berpengaruh terhadap kinerja aparat pemerintah daerah.

\section{Pengujian Variabel Pemoderasi}

Tabel 6

Hasil Uji Moderated Regression Analysis

\begin{tabular}{|c|c|c|c|}
\hline NO. & Persamaan & Nilai $\mathbf{F}$ & $\underset{R^{2}}{\operatorname{Adj} .}$ \\
\hline \multirow[t]{3}{*}{1} & $\mathrm{KAPD}=\alpha+\beta 1 . \mathrm{PPA}+\mathrm{e}$ & \multirow{2}{*}{19,559} & \multirow{3}{*}{0,239} \\
\hline & KAPD $=19,735+0,492 \mathrm{PPA}+\mathrm{e}$ & & \\
\hline & $\begin{array}{lll}\text { Sig } & (0,000) & (0,000)\end{array}$ & 0,000 & \\
\hline \multirow[t]{3}{*}{2} & $\mathrm{KAPD}=\alpha+\beta 1 . \mathrm{PPA}+\beta 2 . \mathrm{KO}+\mathrm{e}$ & \multirow{2}{*}{39,750} & \multirow{3}{*}{0,568} \\
\hline & $\mathrm{KAPD}=6,852+0,430 \mathrm{PPA}+0,384 \mathrm{KO}+\mathrm{e}$ & & \\
\hline & Sig $\quad(0,36)+(0,000)+(0,000)$ & 0,000 & \\
\hline \multirow[t]{3}{*}{3} & $\mathrm{KAPD}=\alpha+\beta 1 . \mathrm{PPA}+\beta 2 . \mathrm{KO}+\beta 3 . \mathrm{PPA} * \mathrm{KO}+\mathrm{e}$ & \multirow{2}{*}{26,499} & \multirow{3}{*}{0,565} \\
\hline & $\mathrm{KAPD}=22,093-0,077 \mathrm{PPA}+0,005 \mathrm{BO}+0,013 \mathrm{PPA} * \mathrm{BO}+\mathrm{e}$ & & \\
\hline & Sig $\quad(0,280)+(0,909)+(0,993)+(0,449)$ & 0,000 & \\
\hline \multirow[t]{3}{*}{4} & $\mathrm{KAPD}=\alpha+\beta 1 . \mathrm{BO}+\mathrm{e}$ & \multirow{2}{*}{22,604} & \multirow{3}{*}{0,268} \\
\hline & $\mathrm{KAPD}=19,096+0,578 \mathrm{BO}+\mathrm{e}$ & & \\
\hline & $\begin{array}{lll}\text { Sig } & (0,000) & (0,000) \\
\end{array}$ & 0,000 & \\
\hline \multirow[t]{3}{*}{5} & $\mathrm{KAPD}=\alpha+\beta 1 . \mathrm{BO}+\beta 2 . \mathrm{KO}+\mathrm{e}$ & \multirow{2}{*}{25,227} & \multirow{3}{*}{0,451} \\
\hline & $\mathrm{KAPD}=13,071+0,340 \mathrm{BO}+0,323 \mathrm{KO}+\mathrm{e}$ & & \\
\hline & Sig $\quad(0,000)+(0,006)+(0,000)$ & 0,000 & \\
\hline \multirow[t]{3}{*}{6} & $\mathrm{KAPD}=\alpha+\beta 1 . \mathrm{BO}+\beta 2 . \mathrm{KO}+\beta 3 . \mathrm{BO} * \mathrm{KO}+\mathrm{e}$ & \multirow{2}{*}{19,277} & \multirow{3}{*}{0,482} \\
\hline & $\mathrm{KAPD}=57,840-1,411 \mathrm{BO}-0,860 \mathrm{~K} 0+0,046 \mathrm{BO} * \mathrm{KO}+\mathrm{e}$ & & \\
\hline & $\begin{array}{lllll}\text { Sig } & (0,10) & (0,100) & (0,137) & (0,041) \\
\end{array}$ & 0,000 & \\
\hline \multirow[t]{3}{*}{7} & $\mathrm{KAPD}=\alpha+\beta 1 . \mathrm{GK}+\mathrm{e}$ & \multirow{2}{*}{30,391} & \multirow{3}{*}{0,333} \\
\hline & $\mathrm{KAPD}=15,810+0,430 \mathrm{GK}+\mathrm{e}$ & & \\
\hline & $\begin{array}{lll}\text { Sig } & (0,000) & (0,000) \\
\end{array}$ & 0,000 & \\
\hline \multirow[t]{3}{*}{8} & $\mathrm{KAPD}=\alpha+\beta 1 . \mathrm{GK}+\beta 2 . \mathrm{KO}+\mathrm{e}$ & \multirow{2}{*}{27,838} & \multirow{3}{*}{0,476} \\
\hline & $\mathrm{KAPD}=11,475+0,269 \mathrm{GK}+0,296 \mathrm{KO}$ & & \\
\hline & $\begin{array}{lll}\text { Sig } & (0,001) & (0,001) \\
\end{array}$ & 0,000 & \\
\hline \multirow[t]{3}{*}{9} & $\mathrm{KAPD}=\alpha+\beta 1 . \mathrm{GK}+\beta 2 . \mathrm{KO}+\beta 3 . \mathrm{GK}^{*} \mathrm{KO}+\mathrm{e}$ & \multirow{2}{*}{22,630} & \multirow{3}{*}{0,548} \\
\hline & $\mathrm{KAPD}=55,743-0,727 \mathrm{GK}-0,925 \mathrm{KO}+0,027 \mathrm{GK} * \mathrm{KO}+\mathrm{e}$ & & \\
\hline & $\begin{array}{lllll}\text { Sig } & (0,002) & (0,070) & (0,058) & (0,012) \\
\end{array}$ & 0,000 & \\
\hline
\end{tabular}

Sumber: Data primer, diolah (2014) 
Setelah dilakukan pengujian dengan analisis regresi berganda terhadap hipotesis pertama diperoleh hasil bahwa partisipasi penyusunan anggaran berpengaruh terhadap kinerja aparat pemerintah daerah. Hasil penelitian ini mendukung penelitian yang dilakukan oleh Purwandani (2012) dan Ayuningtias (2013) terdapat pengaruh yang signifikan antara partisipasi penyusunan anggaran terhadap kinerja aparat pemerintah daerah. Hasil ini menunjukkan bahwa pemerintah Kabupaten Temanggung telah menerapkan partisipasi dalam penyusunan anggaran.

Hasil pengujian menunjukkan budaya organisasi tidak berpengaruh terhadap kinerja aparat pemerintah daerah. Hasil Penelitian ini mendukung penelitian yang dilakukan oleh Purwanto (2013) bahwa tidak terdapat pengaruh antara budaya organisasi dengan kinerja karyawan. Hasil ini menunjukkan bahwa jika terjadi perubahan budaya organisasi maka tidak akan berpengaruh pada kinerja karyawan.

Hasil pengujian menunjukkan bahwa terdapat pengaruh variabel gaya kepemimpinan terhadap kinerja aparat pemerintah daerah,. Hasil penelitian ini mendukung penelitian yang dilakukan oleh dan Sumarno (2005) terdapat pengaruh yang signifikan antara gaya kepemimpinan terhadap kinerja aparat pemerintah daerah. Hasil ini menunjukkan bahwa pemerintah Kabupaten Temanggung telah menerapkan gaya kepemimpinan dalam kinerja aparat pemerintah daerah.

Hasil pengujian menunjukkan bahwa komitmen organisasi tidak mampu memoderasi pengaruh partisipasi penyusunan anggaran terhadap kinerja aparat pemerintah daerah. Hasil penelitian ini tidak sesuai dengan penelitian Wulandari (2011) dan Ayuningtias (2013). Dengan kurangnya tingkat kesesuaian antara partisipasi penyusunan anggaran maka akan berpengaruh terhadap kinerja aparat pemerintah daerah.

Hasil menunjukkan bahwa komitmen organisasi mampu memoderasi budaya organisasi terhadap kinerja aparat pemerintah daerah. Hasil penelitian ini tidak sesuai dengan penelitian yang dilakukan oleh Setyarto (2008) dengan kurangnya komitmen yang ditunjukkan antar pemimpin dan bawahan maka tidak akan mempengaruhi budaya sebuah organisasi dalam beragam cara, menanamkan serta mendukung pembentukan persepsi karyawan dalam suatu organisasi.

Hasil dari analisis regresi terhadap hipotesis yang keenam dapat dilihat bahwa 
komitmen organisasi mampu memoderasi gaya kepemimpinan terhadap kinerja aparat pemerintah daerah.

\section{SIMPULAN, KETERBATASAN, DAN SARAN}

Berdasarkan hasil penelitian maka dapat disimpulkan bahwa partisipasi penyusunan anggaran dan gaya kepemimpinan berpengaruh terhadap kinerja aparat pemerintah daerah Kabupaten Temanggung. Sementara itu, budaya organisasi tidak berpengaruh terhadap kinerja aparat pemerintah daerah Kabupaten Temanggung. Sedangkan untuk pengujian variabel pemoderasi menunjukkan bahwa komitmen organisasi tidak mampu memoderasi pengaruh partisipasi penyusunan anggaran terhadap kinerja aparat pemerintah daerah Kabupaten Temanggung. Namun, komitmen organisasi mampu memoderasi pengaruh budaya organisasi terhadap kinerja aparat pemerintah daerah Kabupaten Temanggung dan pengaruh gaya kepemimpinan terhadap kinerja aparat pemerintah daerah Kabupaten Temanggung.

Penelitian ini terdapat keterbatasan kekurangan yang ditemukan setelah dilakukan analisis data, antara lain penelitian ini hanya tiga variabel independen untuk mempengaruhi kinerja aparat pemerintah daerah. Adjusted $R_{2}$ hanya sebesar 46,9\%. Penelitian ini hanya menggunakan satu variabel pemoderasi yang memoderasi hubungan partisipasi penyusunan anggaran, budaya organisasi, gaya kepemimpinan, dan kinerja aparat pemerintah daerah yaitu komitmen organisasi. Penelitian ini menerapkan metoda survei dengan menggunakan kuesioner tanpa dilengkapi wawancara atau pertanyaan lisan, sehingga peneliti tidak dapat mengontrol jawaban responden yang bisa jadi bukan jawaban sebenarnya.

Ada beberapa saran yang dikemukakan yaitu pada penelitian yang akan datang sebaiknya menambahkan variabel yang belum dimasukkan dalam penelitian ini seperti kepuasan kerja, desentralisasi, dan prestasi kerja, serta menambahkan variabel pemoderasi tidak hanya variabel komitmen organisasi seperti variabel kepuasan kerja dan kejelasan sasaran anggaran. Teknik pengumpulan data tidak hanya dilakukan dengan penyebaran kuesioner, sebaiknya peneliti selanjutnya mengumpulkan data dengan melakukan teknik wawancara secara langsung, agar dapat memperoleh informasi yang lebih lengkap. 


\section{DAFTAR PUSTAKA}

Aisyah, Siti. 2014. "Pengaruh Good Governance, Gaya Kepemimpinan, Komitmen Organisasi dan Budaya Organisasi terhadap Kinerja Pemerintah Daerah Studi pada Pemerintah Daerah Kabupaten Kampar". JOM VEKON. Pekanbaru: Universitas Riau. [Online]. Didapatkan: http://download.portalgaruda.or [5 Januari 2014].

Anthony, Robert. N dan Govindarajan, Vijay. 2009. Sistem Pengendalian Manajemen. Jakarta: Salemba Empat.

Apriliyanti, Anna. 2013. "Pengaruh Partisipasi Anggaran terhadap Senjangan Anggaran dengan Komitmen Organisasi, Motivasi, Ketidakpastian Lingkungan, dan Keterlibatan Kerja sebagai Variabel Pemoderasi”. Yogyakarta: Universitas Ahmad Dahlan.

Arifin, Beny W. 2012. "Pengaruh Partisipasi Penyusunan Anggaran, Kejelasan Sasaran Anggaran, Pengendalian Akuntansi, dan Sistem Pelaporan terhadap Akuntabilitas Kinerja Instansi Pemerintah Daerah dengan Komitmen Organisasi sebagai Variabel Pemoderasi”. Jurnal Akuntansi dan Investasi (JAI) Yogyakarta: Universitas Muhammadiyah Yogyakarta. Hal 19-41, Vol 13 No. 1.

Arifin, Solikhun. 2012. "Pengaruh Partisipasi Penyusunan Anggaran terhadap Kinerja Aparat Pemerintah Daerah : Komitmen Organisasi, Budaya Organisasi dan Gaya Kepemimpinan sebagai Variabel Moderasi”. Skrirpsi. Semarang: Universitas Diponegoro. [Online]. Didapatkan: http://eprints.undip.ac.id [27Oktober 2013].

Ayuningtias, Tina. 2013. "Pengaruh Partisipasi Penyusunan Anggaran terhadap Kinerja Aparat Pemerintah Daerah: Budaya Organisasi dan Komitmen Organisasi sebagai Variabel Pemoderasi, Studi pada Pemerintah Kabupaten Klaten”. Yogyakarta: Universitas Ahmad Dahlan.

Baihaqi, Muhammad Fauzan, 2010. "Pengaruh Gaya Kepemimpinan terhadap Kepuasan Kerja dan Kinerja dengan Komitmen Organisasi sebagai Variabel Intervening”. Skripsi. Semarang: Universitas Diponegoro. [Online]. Didapatkan: http://eprints.undip.ac.id_[27 Oktober 2013].

Bambang, Sardjito dan Osmad Muthaher. 2007. "Pengaruh Partisipasi Penyusunan Anggaran terhadap Kinerja Aparat Pemerintah Daerah: Budaya Organisasi dan Komitmen Organisasi sebagai Variabel Moderating. Simposium Nasional 
Akuntansi X.

Dianita, Restu agusti, dan Al Azhar L. "Pengaruh Partisipasi Penyusunanan Anggaran terhadap Kinerja Aparat Pemerintah Daerah: Komitmen Organisasi dan Gaya Kepemimpinan sebagai Variabel Moderating”. Jurnal Ekonomi vol 17 no 3. Riau: Universitas Riau.

Ghozali, Imam. 2006. Aplikasi Analisis Multivariate dengan Program SPSS. Edisi 4. Semarang: Badan Penerbit Universitas Diponegoro.

Indriantoro, Nur dan Bambang Supomo. 1999. Metodologi Penelitian Bisnis. Yogyakarta: BPFE UGM.

Larasati, Anggi Christina. 2009. "Pengaruh Komitmen Organisasi dan Partisipasi Anggaran terhadap Kesenjangan Anggaran Studi pada Dinas Sosial Provinsi D.I. Yogyakarta”. Skripsi. Universitas Ahmad Dahlan.

Mardiasmo. 2002. Akuntansi Sektor Publik. Yogyakarta: Andi Offset.

Mardiasmo. 2005. Akuntansi Sektor Publik. Yogyakarta: Andi Offset.

Mediaty. 2013. "Pengaruh Partisipasi Penyusunan Anggaran terhadap Kinerja Aparatur Pemerintah Daerah Dengan Budaya Organisasi dan Komitmen Organisasi sebagai Moderator (Studi Kasus pada Pemerintah Kabupaten Baru Sul-Sel)”. Skripsi. Semarang: Universitas Diponegoro.

Mulyadi. 2001. Akuntansi Manajemen. Yogyakarta: Salemba Empat.

Noviyanti. 2014. "Pengaruh Partisipasi Penyusunan Anggaran, Gaya Kepemimpinan, dan Komitmen Organisasi terhadap Kinerja Aparat Pemerintah Daerah dengan Budaya Organiasasi sebagai Variabel Pemoderasi Studi pada Pemerintah Kabupaten Belitung”. Skripsi. Yogyakarta: Universitas Ahmad Dahlan.

Pemerintah Kabupaten Temanggung [Online]. Didapatkan: http://www.temanggungkab.go.id [10> Mei 2014].

Purwandani, Trisna. 2012. “Analisis Pengaruh Partisipasi Penyusunan Anggaran terhadap Kinerja Aparat Pemerintah Daerah: Budaya Organisasi dan Komitmen Organisasi sebagai Variabel Moderating Survei pada Karyawan Pemda Kabupaten Klaten”. Skripsi. Surakarta: Universitas Muhammadiyah 
Surakarta.

Purwanto, Hari. 2013. "Pengaruuh Kepemimpinan dan Budaya Organisasi terhadap Kinerja Karyawan”. Jurnal Ekomaks Vol 2 No 2. Madiun: STIE Dharma Iswara Madiun.

Rafika, Anggaraeni. 2009. "Pengaruh Partisipasi Anggaran dan Komitmen Organisasi terhadap Kinerja SKPD Pemerintahan Kabupaten Labuhan Batu”. Skripsi Akuntansi Ekonomi Universitas Sumatera Utara [Online]. Didapatkan: http://respository.usu.ac.id [16> Januari 2015].

Republika Indonesia. Keputusan MENDAGRI R.1 No. 13 Tahun 2006 tentang Pedoman Pengelolaan Keuangan Daerah. Jakarta, Indonesia.

Robbins, Stephen. 2006. Perilaku Organisasi. Edisi Kesepuluh. Penerjemah Benyamin Molan. Jakarta: PT. Indeks.

Santoso, Pamudji. 2009. "Pengaruh Partisipasi dan Profesionalisme Aparat terhadap Efektivitas Penggunaan Anggaran dengan Struktur Organisasi Desentralisasi sebagai Variabel Pemoderasi: Studi pada SKPD Temanggung”. Tesis. Semarang: Universitas Diponegoro.

Setyarto. 2008. "Pengaruh Gaya Kepemimpinan, Profesionalisme, Komitmen Organisasi, dan Kepuasan Kerja terhadap Kinerja Karyawan Bagian Akuntansi dengan Budaya Organisasi sebagai Moderasi (Survey pada Koperasi Simpan Pinjam di Wilayah Kota Madya Surakarta)”. Tesis. Surakarta: Universitas Muhammadiyah Surakarta. [Online]. Didapatkan: http://eprints.undip.ac.id [12 April 2014].

Sumarno, John. 2005. "Pengaruh Komitmen Organisasi dan Gaya Kepemimpinan terhadap Hubungan antara Partisipasi Anggaran dan Kinerja Manajerial". Simposium Nasional VIII.

Susilowati, Kartika. 2013. "Pengaruh Partisipasi Penyusunan Anggaran terhadap Kinerja Manajerial Dengan Job Relevant Information dan Komitmen Organisasi sebagai Moderating Variable”. Skripisi. Yogyakarta: Universitas Ahmad Dahlan.

Utari, Nuraeni. 2009. "Studi Fenomenologis tentang Proses Penyusunan Anggaran Berbasis Kinerja pada Pemerintah Kabupaten Temanggung”. Tesis. Semarang: Universitas Diponegoro. [Online]. Didapatkan: http://eprints.undip.ac.id [4 April 2014]. 
Wulandari, Nur Endah. 2011. "Pengaruh Partisipasi Penyusunan Anggaran terhadap Kinerja Aparat Pemerintah Daerah: Kepuasan Kerja dan Komitmen Organiasasi sebagai Variabel Moderating”. Skripsi. Semarang: Universitas Diponegoro. 